\section{Somatic Embryogenesis of Carrot in Bioreactor Culture Systems}

\author{
Whei-Lan Teng ${ }^{1}$, Yann-Jiun Liu, Yu-Ching Tsai, and Tai-Sen Soong \\ Agricultural Biotechnology Division, Development Center for Biotechnology, \\ 81 Chang Hsing Street, Taipei, Taiwan, Republic of China
}

Additional index words. Daucus carota, fermentor, foaming

\begin{abstract}
A bioreactor was used to establish a scale-up system for somatic embryogenesis in 'Scarlet' carrot (Daucus carota $\mathrm{L}$.). At a cell density of 1-2 $\times 10^{6}$ cells $/ \mathrm{ml}$, mature and germinating embryos could be observed within 4 to 5 weeks. As cell density exceeded $2 \times$ $10^{6}$ cells/ml, the culture turned darker yellow, and embryo development was inhibited. Cell densities below $10^{6} \mathrm{cells} / \mathrm{ml}$ resulted in abnormal embryos. Bioreactor design had a critical impact on somatic embryogenesis due to various types and the strength of shear forces generated. In this study, an air-lift bioreactor was selected from three different types (spinner flask, screen column bioreactor, and air lift) because it resulted in the highest biomass production and somatic embryogenesis. Foaming was eliminated by preculture of embryogenic cells in flasks; cells were then sieved on a $60-\mu \mathrm{m}$ polyester screen and thoroughly rinsed with distilled water before being transferred to the bioreactor. Such preculture for at least 10 days significantly increased the regeneration of somatic embryos. During somatic embryogenesis, dissolved $\mathrm{O}_{2}$ concentrations decreased to $33 \%$ of saturation, and then increased up to $80 \%$ when embryo development approached maturity and mature embryos germinated. Bioreactor-cultured embryos germinated with relatively short cotyledons and long roots, whereas flask-cultured embryos germinated with relatively long cotyledons and short roots.
\end{abstract}

Somatic embryogenesis is recognized as a technique for producing large quantities of a clone and consequently is of great interest in development of artificial seeds (Redenbaugh et al., 1987). Somatic embryogenesis in liquid culture, particularly in a bioreactor, is thought to be an economical way for future commercialization of artificial seeds. However, few articles on plant propagation using bioreactors have been published (Akita and Takayama, 1988; Chen et al., 1987; Greidziak et al., 1990; Levin et al., 1988; Park et al., 1989; Preil et al., 1988; Stuart et al., 1987; Takayama et al., 1991; Teng et al., 1993). In most cases, mass propagation systems in bioreactors are not fully developed for practical application.

In establishing a bioreactor culture system, certain factors are important, including cell density, bioreactor design, foaming, preculture of embryogenic cells, and dissolved $\mathrm{O}_{2}$ (DO) concentrations. Previous researchers showed that the amount of $\mathrm{O}_{2}$ required for somatic embryogenesis was species dependent. For example, poinsettia (Euphorbia pulcherrima Willd.) and alfalfa (Medicago sativa L.) required DO levels of $60 \%$ and $70 \%$, respec-

Received for publication 8 Nov. 1993. Accepted for publication 7 July 1994. This research was supported by the U.S. Dept. of Agriculture and Council of Agriculture in Taiwan, project no. TW-AES-42. The cost of publishing this paper was defrayed in part by the payment of page charges. Under postal regulations, this paper therefore must be hereby marked advertisement solely to indicate this fact.

${ }^{1}$ To whom reprint requests should be addressed. Current address: Hong Kong Institute of Biotechnology, 2 Biotechnology Ave., 12 Miles, Tai Po Road, Shatin, N.T., Hong Kong. tively, to promote somatic embryogenesis (Beck, 1987; Preil et al., 1988; Stuart et al., 1987). Conflicting results have been reported for carrot. Kessell and Carr (1972) reported that DO levels higher than $16 \%$ significantly inhibited somatic embryogenesis, while, according to Jay et al. (1992), DO at $100 \%$ promoted production of carrot embryos.

The level of success of a bioreactor culture system is often evaluated against the flask culture system because the former can be considered as a scale-up of a flask culture system. Usually, bioreactor cultures have a lower dry weight gain than cultures grown in shaken flasks, and the level of regeneration in a bioreactor is also lower than that in a flask (Greidiak et al., 1990; Kessell and Carr, 1972; Stuart et al., 1987). The conversion rate of somatic embryos regenerated in a bioreactor is even lower. For example, the conversion of somatic embryos of alfalfa in a bioreactor was $2 \%$ to $3 \%$, compared with $30 \%$ in flask culture (Stuart et al., 1987).

Most of the research regarding bioreactor culture has focused on increasing regeneration of somatic embryos and, subsequently, conversion rate. Embryos formed in bioreactors were reported to resemble morphologically those formed or developed in shaken flasks (Greidziaketal., 1990). However, to our knowledge, the influence of bioreactor and flask culture systems on the morphology of germinating embryos has not been reported.

In a previous paper, we reported bioreactor culture of lettuce (Lactuca sativa $\mathrm{L}$.) where the regeneration level was as high as that in 125$\mathrm{ml}$ flasks (Teng et al., 1992). In the current study, we report on somatic embryogenesis of carrot and the morphological changes of embryos after germination in a bioreactor.
Seeds of 'Scarlet' carrot were surface-sterilized with $1 \% \mathrm{NaOCl}$ for $5 \mathrm{~min}$ and then rinsed thoroughly with sterile distilled water. Seeds were then germinated aseptically on Murashige and Skoog (1962) (MS) basal medium. Cotyledons were cut into pieces and placed in $90 \times 10-\mathrm{mm}$ petri dishes containing $20 \mathrm{ml}$ callus induction medium consisting of MS basal salts supplemented with (mg.liter ${ }^{-1}$ ) 0.5 thiamine- $\mathrm{HCl}, 0.4$ pyridoxine- $\mathrm{HCl}, 0.5$ nicotinic acid, 100 myo-inositol, plus $2 \%$ sucrose, $4.5 \mu_{\mathrm{M}}$ 2,4-dichlorophenoxyacetic acid (2,4-D), $1.0 \mu_{\mathrm{M}}$ kinetin, and $0.8 \%$ Difco Bacto agar. The $\mathrm{pH}$ of the medium was adjusted to 5.4-5.5 before autoclaving at $121 \mathrm{C}$ and 124 $\mathrm{kPa}$ for $20 \mathrm{~min}$. Cotyledon explants were incubated at a 16/8-h day/night cycle of $25 / 23 \mathrm{C}$ with a 16 -h photoperiod of $10 \mu \mathrm{mol} \cdot \mathrm{m}^{-2} \cdot \mathrm{s}^{-1}$ provided by cool-white fluorescent lamps. Callus was transferred to $125-\mathrm{ml}$ flasks containing $50 \mathrm{ml}$ liquid medium to establish suspension cultures after a 2-month induction period. The liquid culture medium was the same as the callus induction medium without addition of agar. All flasks were placed on orbital shakers (125 rpm) at $25 \mathrm{C}$ under continuous cool-white fluorescent light of 10 $\mu \mathrm{mol} \cdot \mathrm{m}^{-2} \cdot \mathrm{s}^{-1}$.

After 3 weeks of culture, the suspensions were first sieved on a $400-\mu \mathrm{m}$ and then on a 60 $\mu \mathrm{m}$ polyester screen. Cells remaining on this screen were transferred to fresh medium. Cell growth was measured by the volume increase of packed cell mass. The cell suspension was subcultured at the end of the exponential growth phase (every 10 days).

For somatic embryogenesis, a cell suspension maintained for 1 year was sieved on a 60$\mu \mathrm{m}$ polyester screen and thoroughly rinsed with distilled water. Packed cells were then placed in a culture medium free of growth regulators (MS0). Mature somatic embryos were visible in 4 to 5 weeks.

To determine the optimal cell density for bioreactor culture, $<10^{4}, 10^{5}$, and $1,2, \ldots, 8 \times$ $10^{6}$ cells $/ \mathrm{ml}$ culture medium were inoculated separately into $125-\mathrm{ml}$ flasks. This experiment was repeated three times, with each time having six replications

In this study, a commercially available spinner flask (Hario, Japan), a specifically designed air-lift bioreactor (Fig. 1), and a screen column bioreactor (Teng et al., 1993) were used. The working volumes for the spinner flask, air-lift, and screen column bioreactors were $0.5,1.2$, and 2.0 liters, respectively. The spinner flask was equipped with a two-blade propeller used to agitate the culture medium and inoculum. The screen column bioreactor also had a two-blade propeller for agitating the culture medium and inoculum. However, the screen column was designed to isolate the aeration area from the inoculum to prevent foaming caused by the interaction between air bubbles and inoculum during the culture period. The design was described by Teng et al. (1993). There was no propeller in the air-lift bioreactor. Mixing of the culture was driven by movement of air bubbles emitted from an 


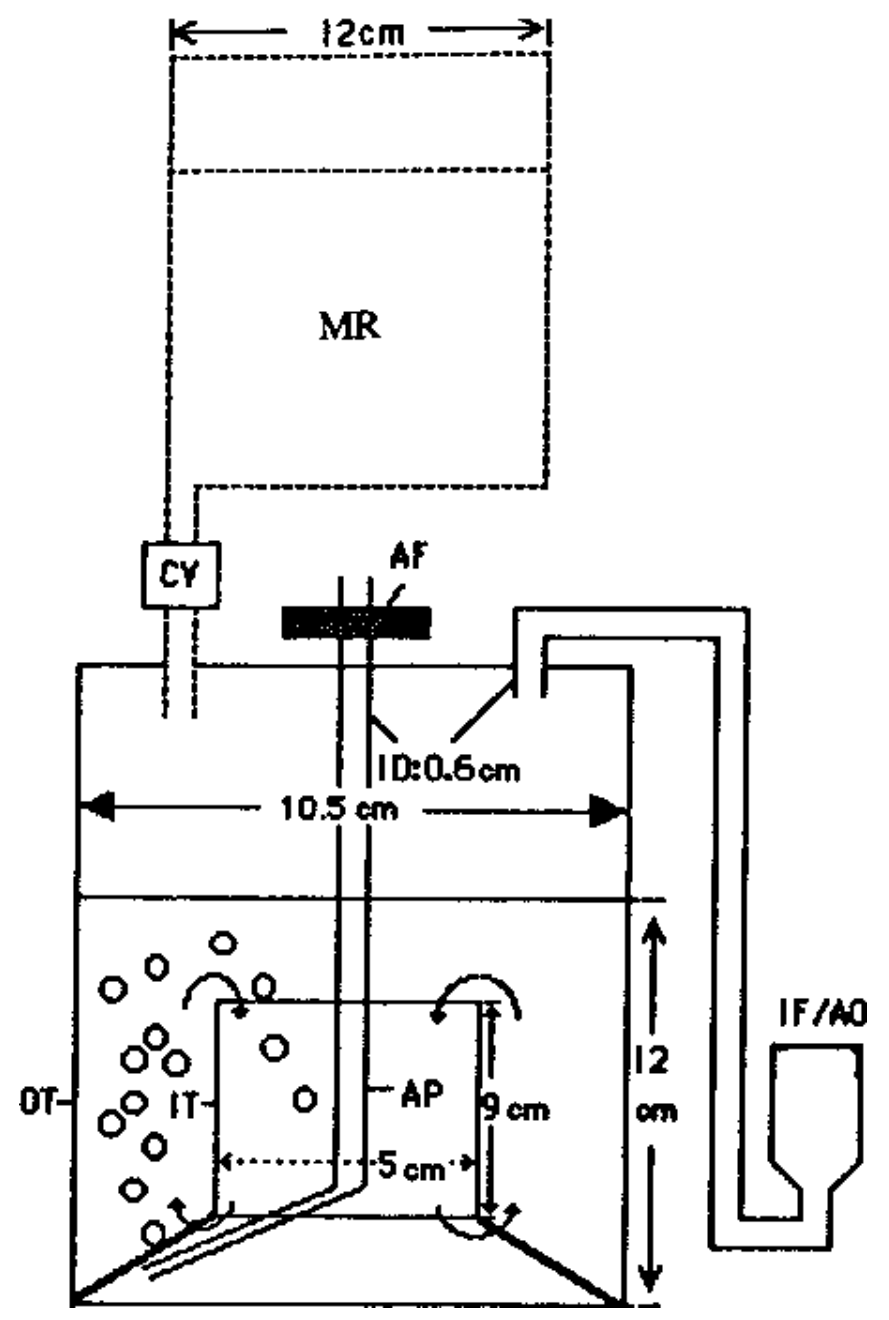

Fig. 1. Schematic of the air-lift bioreactor. Dashed lines represent the water supply system. $A F=$ air filter, $\mathrm{AP}=$ aeration pipe, $\mathrm{CV}=$ control valve, $\mathrm{IF} / \mathrm{AO}=$ inoculation funnel/air outlet, $\mathrm{MR}=$ medium $(1 / 4 \mathrm{MS} 0)$ reservoir, $\mathrm{ID}=$ inner diameter, $\mathrm{IT}=$ inner tube, $\mathrm{OT}=$ outer tube.

aeration pipe inserted through the inner tube with one end close to the bottom of the outer tube (Fig. 1). Movement of inoculum and culture medium was from the bottom of the bioreactor through the interspace between the outer tube and the inner tube to the top of the inner tube, then down through the inner tube to the bottom of the bioreactor. All necessary tubing of the air-lift bioreactor (aeration pipes, water supply pipes, inoculation pipes) was manufactured from autoclavable silicone and Teflon. Air was channeled to the medium by bubbling at a rate of $1.0 \mathrm{vvm}$ (liter air/liter medium/min). Medium loss from evaporation due to aeration was replenished by an automatic medium supply system, where the $\mathrm{pH}$ of the medium was adjusted to $5.4-5.5$ before autoclaving. A quarter-strength MS0 medium was added for replenishment, because adding full-strength MS0 medium would have inhibited somatic embryogenesis. Although not measured precisely, medium replenishment rate depended on aeration rate and was estimated at 0.8 to 1.5 liters over the 2 - to 3 -week culture period.

The inoculation process for all three types of bioreactors was identical. Bioreactors and culture media were sterilized separately. Inoculum was prepared by sieving the cell sus- pensions on a $60-\mu \mathrm{m}$ polyester screen followed by a thorough rinse of cells with distilled water, and the remaining cells on the screen were then added to the culture medium in an inoculation jar. During inoculation, an inoculation funnel (IF/AO in Fig. 1) at the end of the inoculation pipe was inserted into an inoculation jar and inoculum with culture medium was pumped into the bioreactor. Only the inoculation pipe and inoculation jar were in the laminar flow hood during inoculation. After inoculation, the IF was plugged with sterilized cotton and wrapped with sterilized aluminum foil, and functioned as an air outlet (AO). Using this inoculation process, only one incident of contamination occurred in our experiments. After inoculation, the spinner flask and screen column bioreactor were agitated at $110 \mathrm{rpm}$. All bioreactors were placed under the same environmental conditions as the cell suspension cultures.

Since embryogenic cells from different subcultures may differ in the number and developmental stage of regenerated somatic embryos, flask culture was conducted concurrently in 125-ml flasks in the same culture room so that levels of somatic embryogenesis could be used for comparison with that in the bioreactor. For each experiment, flask cul- tures (six replications) and the bioreactor cultures (four replications) were initiated from embryogenic cells of the same age and history. Four bioreactors of each type were tested at the same time. Most experiments were conducted three times.

Somatic embryogenesis was not synchronous. At the end of culture, embryos of various developmental stages occupied almost all the biomass volume. Only a small portion of biomass consisted of structures other than embryos. Thus, embryo regeneration was measured by means of an index calculated as $100 \%$ $\times$ (the biomass weight after culture/inoculum weight $)_{\text {bioreactor }} /$ (the biomass weight after culture/inoculum weight $)_{\text {flask }}$. The regeneration index of torpedo-stage embryos was calculated as $100 \% \times$ (number of torpedo-stage embryos/number of total embryos) bioreactor $_{\text {I }}$ (number of torpedo-stage embryos/number of total embryos) $)_{\text {flask }}$.

Factors that influenced cell growth and differentiation were tested. These factors included inoculation density, bioreactor design, foaming, preculture of embryogenic cells, and DO level. Since the bioreactor was not equipped with an on-line DO monitor, DO was measured off-line by a dissolved $\mathrm{O}_{2}$ meter (model 58; Yellow Springs Instrument Co., Yellow Springs, Ohio) equipped with YSI 5730 dissolved $\mathrm{O}_{2}$ probe.

\section{Results and Discussion}

Culture density. After 14 days of culture, suspensions of $1 \times 10^{6}$ and $2 \times 10^{6}$ cells $/ \mathrm{ml}$ turned from pale yellow to milky white. Microscopic examination showed that most embryos were in the proglobular development state. At a cell density $>2 \times 10^{6}$ cells $/ \mathrm{ml}$, the suspension turned darker yellow. The higher the cell density, the darker the color. Most of these cells remained in the embryogenic cell stage and some were in the proglobular stage. Cell density $<10^{6}$ cells $/ \mathrm{ml}$ did not affect the ability of embryogenic cells to regenerate but reduced embryo quality and slowed the regeneration rate. Embryogenic cells regenerated somatic embryos faster, but with a higher occurrence of abnormal embryos. The lower the cell density, the faster the somatic embryogenesis and the higher the percentage of abnormal embryos.

Overinoculation appeared to be the reason for embryogenic cells to remain at the proglobular stage at cell densities $>2 \times 10^{6}$ cells/ml. Embryogenesis can resume by reducing the cell density. When one-third of the packed cell mass was transferred to fresh medium on day 14, and one-third of the packed cell mass from the diluted cell suspension was transferred again at the end of week 4 to another fresh medium, somatic embryogenesis was resumed for suspensions of $4 \times 10^{6}$ cells $/ \mathrm{ml}$. However, mature embryos were observed $\approx 3$ weeks later than that in $1-2 \times 10^{6}$ cells $/ \mathrm{ml}$ without dilution. Embryogenesis was not resumed for suspensions of $6 \times 10^{6}$ and 8 $\times 10^{6}$ cells $/ \mathrm{ml}$. Moreover, suspensions of $1 \times$ $10^{6} \mathrm{cells} / \mathrm{ml}$ developed into abnormal embryos with deformed cotyledons or swollen hypoco- 
Table 1. Influence of bioreactor design on somatic embryogenesis of carrot after 3 weeks of culture.

\begin{tabular}{lccc}
\hline \hline & $\begin{array}{c}\text { Embryo } \\
\text { Biomass } \\
\text { increase }\end{array}$ & $\begin{array}{c}\text { Torpedo-stage } \\
\text { embryos as } \\
\text { index }(\%)^{\mathrm{y}}\end{array}$ & $\begin{array}{c}\begin{array}{c}\text { percentage of } \\
\text { total embryos }\end{array} \\
\text { Bioreactor }\end{array}$ \\
Spinner flask & $0.0 \mathrm{c}^{\mathrm{x}}$ & $0.0 \mathrm{c}$ & $0 \mathrm{c}$ \\
Screen column & $2.2 \mathrm{~b}$ & $25.6 \mathrm{~b}$ & $50 \mathrm{a}$ \\
Air-lift & $4.3 \mathrm{a}$ & $60.0 \mathrm{a}$ & $29 \mathrm{~b}$ \\
\hline
\end{tabular}

${ }^{2}$ Calculation based on biomass weight/inoculum weight.

${ }^{\mathrm{y}}$ Embryo regeneration index was calculated as: $100 \% \times$ (the biomass weight after culture/inoculum weight $)_{\text {bioreactor }} /(\text { the biomass weight after culture/inoculum weight })_{\text {flask }}$.

${ }^{x}$ Mean separation within columns by Duncan's multiple range test $(P \leq 0.05)$.

tyls. Since the suspensions in the bioreactors were not diluted throughout the whole course of culture, inoculation at a density of $1-2 \times 10^{6}$ cells/ml was selected for further experiments.

Bioreactor type. Bioreactor design had a significant effect on cell growth and embryogenesis. After 3 weeks of bioreactor culture, no signs of growth were evident in the spinner flask bioreactor. Most of the cell mass was broken cells and cell debris.

Regeneration of somatic embryos was visible in the screen column and air-lift bioreactors after 3 weeks of culture. In the screen column bioreactor, the biomass was 2.2 times inoculum weight and the embryo regeneration index was $25.6 \%$ (Table 1). Most of the regenerated embryos accumulated on the screen column.

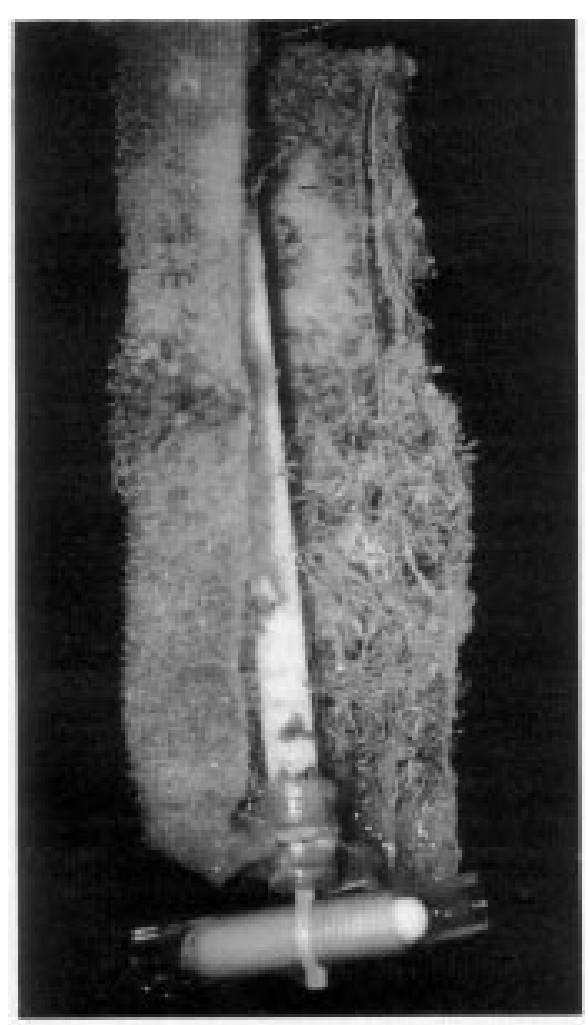

Fig. 2. Accumulation of somatic embryos on the screen column. The screen column was dissected to show that germinating embryos were inserted either with cotyledons inside and roots outside the screen column or with roots inside and cotyledons outside the screen column. All cotyledons inside the screen column were longer than those outside the screen column. Similarly, all roots inside the screen column were longer than those outside the screen column.

${ }^{\mathrm{z} C a l c u l a t i o n}$ based on biomass weight/inoculum weight. used culture medium before inoculating into a bioreactor. Such preculture also increased cell growth and embryo regeneration. During the preculture period, most embryogenic cells were converted to proglobular embryos. With 10 days preculture followed by 18 days culture in the bioreactor, biomass was 8 times inoculum weight and the embryo regeneration index was $54.6 \%$. The regeneration index of torpedo-stage embryos was $20 \%$ (Table 2 ). When 20-day preculture was given, followed by a 10 -day culture in the bioreactor, biomass increased 1.6-fold relative to the 10/18 day combinations. The embryo regeneration index increased by $\approx 20 \%$, and the regeneration index of torpedo-stage embryos nearly doubled to 100\% (Table 2, Fig. 3).

At the end of culture, many germinating embryos were in the bioreactor and the flasks. Germinating embryos formed in the bioreactors were morphologically different from those developed in flasks. These embryos had not appeared different at the mature-embryo stage. Compared to the flask cultures, germinating embryos from the bioreactors had long roots and very short cotyledons. However, germinating embryos from the flasks had long cotyledons and relatively short roots (Table 3 ).

Although studies on germination, acclimatization, and eventual seedling growth from these treatments were not conducted, some germinating and nongerminating embryos from the bioreactors and the flasks were transferred to solid MS0 medium in $7.5 \times 7.5 \times 7.5-\mathrm{cm}$ vessels (Magenta container, GA7; Sigma, St. Louis); $\approx 90 \%$ of them grew to become seedlings. Morphological differences between bioreactor and flask-cultured embryos might also lead to differences in growth rate and other physiological attributes of seedlings during growth and development. However, we did not measure these characteristics.

During somatic embryogenesis, changes in $\mathrm{pH}$ and $\mathrm{DO}$ were measured in the flask cultures. The $\mathrm{pH}$ of the medium increased steadily, by $\approx 2$ units by the end of the 42 days of culture (Table 4). The DO concentration, however, decreased sharply to $36.5 \%$ on day 14 and remained at that level through day 28 . Embryos were in the proglobular to globular stages during the first 14 days of culture, and in the heart and torpedo stages over the next 14 days. DO levels increased again during days 29 to 42 as torpedo-stage embryos approached maturity and mature embryos germinated.

Table 2. Influence of preculture of embryogenic cells on somatic embryogenesis of carrot.

\begin{tabular}{|c|c|c|c|c|}
\hline $\begin{array}{l}\text { Preculture } \\
\text { (days) }\end{array}$ & $\begin{array}{c}\text { Culture } \\
\text { period } \\
\text { (days) }\end{array}$ & $\begin{array}{l}\text { Biomass } \\
\text { increase }^{z}\end{array}$ & $\begin{array}{c}\text { Embryo } \\
\text { regeneration } \\
\text { index }(\%)^{\mathrm{y}}\end{array}$ & $\begin{array}{c}\text { Regeneration } \\
\text { index of } \\
\text { torpedo-stage } \\
\text { embryos } \\
(\%)^{\mathrm{x}}\end{array}$ \\
\hline 0 & 21 & $4.3 \mathrm{c}^{\mathrm{w}}$ & $60.0 \mathrm{~b}$ & \\
\hline 10 & 18 & $8.0 \mathrm{~b}$ & $54.6 \mathrm{~b}$ & $20 \mathrm{~b}$ \\
\hline 20 & 10 & $13.0 \mathrm{a}$ & $73.0 \mathrm{a}$ & $100 \mathrm{a}$ \\
\hline
\end{tabular}

${ }^{y}$ Embryo regeneration index was calculated as: $100 \% \times($ the biomass weight after culture/inoculum weight $)_{\text {bioreactor }} /(\text { the biomass weight after culture/inoculum weight })_{\text {flask }}$.

${ }^{\mathrm{x}}$ Regeneration index of torpedo-stage embryos was calculated as: $100 \% \times$ (number of torpedo-stage embryos/number of total embryos $)_{\text {bioreactor }}$ (number of torpedo-stage embryos/number of total embryos $)_{\text {flask }}$. wMean separation within columns by Duncan's multiple range test $(P \leq 0.05)$ 


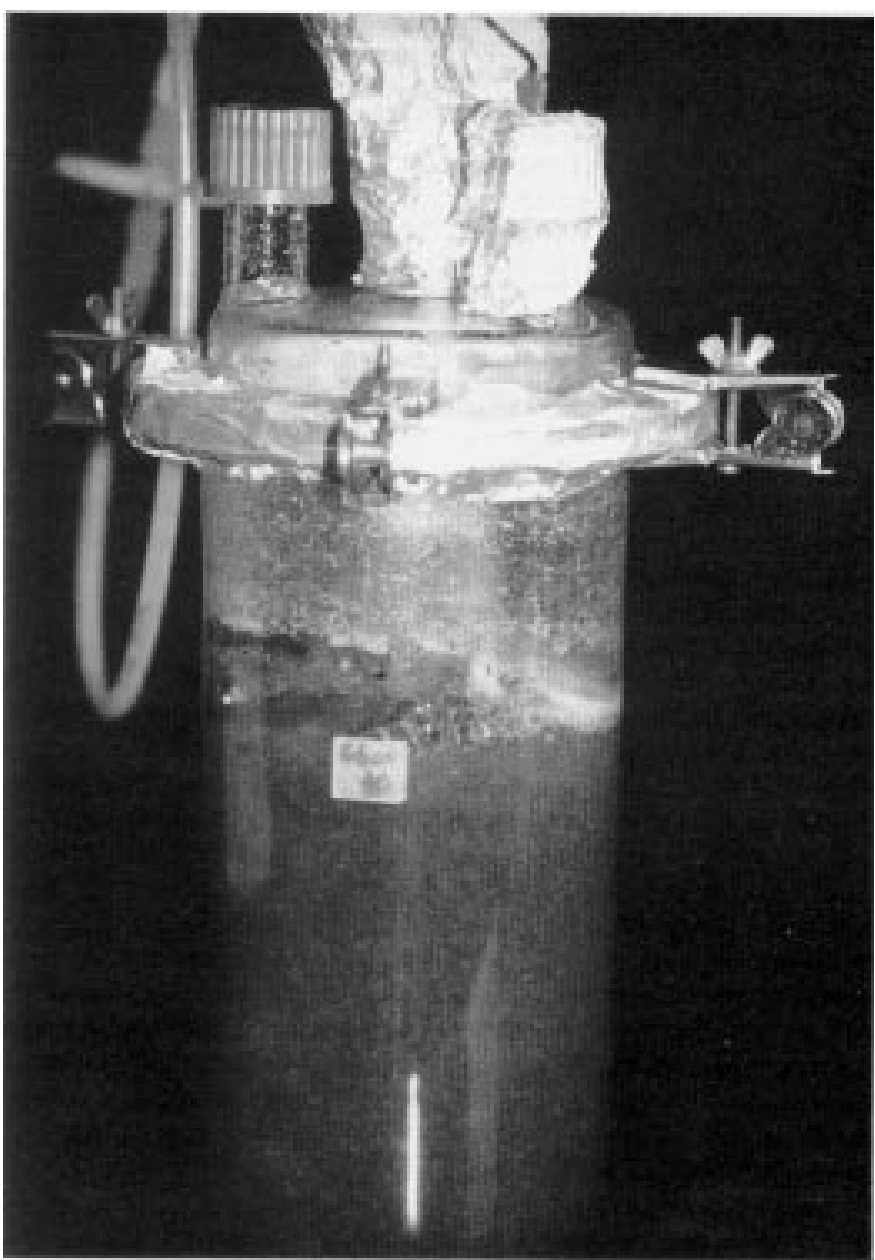

Fig. 3. Regeneration of somatic embryos of carrot after 12 days in the bioreactor. The embryogenic cells were precultured in $125-\mathrm{ml}$ flasks for 20 days before transfer to the bioreactor.

The sharp decrease in DO during the first 14 days was magnified with an increase in inoculation density. The highest inoculation density $\left(8 \times 10^{6}\right.$ cells $\left./ \mathrm{ml}\right)$ resulted in the greatest DO decrease on day 14 (data not presented). During the first 14 days of culture, cells of a density $>2 \times 10^{6}$ cells $/ \mathrm{ml}$ turned to darker yellow and remained at the embryogenic cell stage. Obviously, shaking at 125 rpm could only supply sufficient $\mathrm{O}_{2}$ for embryogenesis of cells at a density of $1-2 \times 10^{6}$ cells $/ \mathrm{ml}$.

Our results contrasted with those of Kessell and Carr (1972), which showed DO levels $>16 \%$ significantly inhibited somatic embryogenesis of carrot. However, our results agree with those reported by Jay et al. (1992) that ample supplies of dissolved $\mathrm{O}_{2}$ promoted somatic embryogenesis in carrot.

Previous reports indicated the $\mathrm{O}_{2}$ requirement to be species specific (e.g., Beck, 1987; Chen et al., 1987; Greidziak et al., 1990; Jay et al., 1992; Kessell and Carr, 1972; Preil et al., 1988; Stuart et al., 1987). The $\mathrm{O}_{2}$ requirement also may vary from cultivar to cultivar within the same species. Since neither Kessell and Carr (1972) nor Jay et al. (1992) indicated the cultivar of carrot used, the possibility of cell line differences cannot be ruled out.

Currently, bioreactor cultures have lower dry weights than cultures grown in shake flasks.
After preculture of 20 days, although the regeneration of torpedo-stage embryos was $100 \%$, embryo regeneration was $27 \%$ lower than that in flask culture (Table 2). However, there is a potential for commercialization of mass propagation in bioreactors if high regeneration frequencies can be obtained. To optimize the culture conditions for maximum regeneration, on-line factor controllers (such as $\mathrm{pH}$ and DO controllers) must be employed to monitor the fluctuation of such factors. Also to be determined is whether factors such as $\mathrm{pH}$ and DO should be maintained at a constant level, since in flask culture, they varied throughout the culture period.

\section{Literature Cited}

Akita, M. and S. Takayama. 1988. Mass propagation of potato tubers using jar fermentor techniques. Acta Hort. 230:55-61.

Beck, A. 1987. Untersuchungen zur somatischen Embryogeneses unter verschiedenen Bioreaktorbedingungen, insbesondere bei $\mathrm{Eu}$ Biologie, Univ. Hamburg, Germany.

Chen, T.H.H., B.G. Thompson, and D.F. Gerson. 1987. In vitro production of alfalfa somatic embryos in fermentation systems. J. Fermentation Technol. 65:353-357.

Greidziak, W., B. Diettrich, and M. Luckner. 1990. Batch cultures of somatic embryos of Digitalis phorbiapulcherrima. Diplomarbeit, Fachbereich
Table 3. Influence of liquid culture systems on morphological changes of germinating embryos of carrot.

\begin{tabular}{lccc}
\hline \hline $\begin{array}{l}\text { Culture } \\
\text { system }\end{array}$ & $\begin{array}{c}\text { Cotyledon } \\
(\mathrm{mm})^{\mathrm{z}}\end{array}$ & $\begin{array}{c}\text { Hypocotyl } \\
\text { length } \\
(\mathrm{mm})\end{array}$ & $\begin{array}{c}\text { Root } \\
(\mathrm{mm})\end{array}$ \\
\hline Bioreactor & $2.1 \mathrm{~b}^{\mathrm{y}}$ & $3.2 \mathrm{a}$ & $26.7 \mathrm{a}$ \\
Flask & $22.3 \mathrm{a}$ & $2.3 \mathrm{a}$ & $15.7 \mathrm{~b}$ \\
\hline
\end{tabular}

${ }^{2}$ Mean separation within columns by Duncan's multiple range test $(P \leq 0.05)$.

yFor bioreactor culture, each mean is the mean of five replications from five bioreactors. Each replication contained three samples from the same bioreactor. Each sample contained 20 to $30 \mathrm{em}$ bryos. For flask culture, each mean represents the mean of five replications from five flasks. Each replication contained three samples from the same flask. Each sample contained 15 embryos.

Table 4. Changes in $\mathrm{pH}$ and dissolved $\mathrm{O}_{2}$ (DO) values (percentage) during somatic embryogenesis of carrot cultured in flasks. The inoculation density was $1-2 \times 10^{6}$ cells $/ \mathrm{ml}$ culture medium.

\begin{tabular}{lcccc}
\hline & \multicolumn{4}{c}{ Culture period (days) } \\
\cline { 2 - 5 } Variable & 0 & 14 & 28 & 42 \\
\hline pH & $5.0 \mathrm{c}^{\mathrm{z}}$ & $5.8 \mathrm{~b}$ & $6.8 \mathrm{a}$ & $7.1 \mathrm{a}$ \\
DO & $83.2 \mathrm{a}$ & $36.5 \mathrm{c}$ & $39.4 \mathrm{c}$ & $69.2 \mathrm{~b}$ \\
\hline
\end{tabular}

${ }^{2}$ Mean separation within rows by Duncan's multiple range test $(P \leq 0.05)$.

lanata in gaslift fermentors. Development and cardenolide accumulation. Planta Medica 56:175-178.

Jay, V., S. Genestier, and J.C. Courduroux. 1992. Bioreactor studies on the effect of dissolved oxygen concentrations on growth and differentiation of carrot (Daucus carota $\mathrm{L}$.) cell cultures. Plant Cell Rpt. 11:605-608.

Kessell, R.H.J. and A.H. Carr. 1972. The effect of dissolved oxygen concentration on growth and differentiation of carrot (Daucus carota) tissue cultures. J. Expt. Bot. 23:996-1007.

Levin, R., V. Gaba, B. Tal, S. Hirsch, D. De Nola, and I.K. Vasil. 1988. Automated plant tissue culture for mass propagation. Bio/Technology 6:1035-1040.

Murashige, T. and F. Skoog. 1962. A revised medium for rapid growth and bioassays with tobacco tissue cultures. Physiol. Plant. 15:473497.

Park, J.M., W.S. Hu, and E.J. Staba. 1989. Cultivation of Artemisia anпиа $\mathrm{L}$. plantlets in a bioreactor containing a single carbon source and a single nitrogen source under submerged culture conditions. Potential application to artemisinin production. Biotechnology Bioengineering 34:1209-1213.

Preil, W., P. Florek, U. Wix, and A. Beck. 1988. Towards mass propagation by use of bioreactors. Acta Hort. 226:99-105.

Redenbaugh, K., P. Viss, D. Slade, and J.A. Fujii. 1987. Scale-up: Artificial seeds, p. 473-493. In: R. Alan (ed.). Plant tissue and cell culture. Liss, New York

Stuart, D.A., S.G. Strickland, and K.A. Walker. 1987. Bioreactor production of alfalfa somatic embryos. HortScience 22:800-809.

Takayama, S., B. Swedlund, and Y. Miwa. 1991. Automated propagation of microbulbs of lilies, p. 112-132. In: I.K. Vasil (ed.). Cell culture and somatic cell genetics of plants. vol. 8. Scale-up and automation in plant propagation. Academic, New York

Teng, W.L., C.P. Lin, and Y.J. Liu. 1993. Regenerating lettuce from suspension culture in a 2-liter bioreactor. HortScience 28:669-671. 